\title{
KARAKTER FASAD BANGUNAN TERMINAL PENUMPANG BANDAR UDARA INTERNASIONAL SOEKARNO-HATTA
}

\author{
Titik Widiyastuti ${ }^{1}$, M.I. Ririk Winandari ${ }^{2}$ \\ ${ }^{1}$ Mahasiswa Pasca Sarjana, Jurusan Arsitektur, FTSP Universitas Trisakti, Jakarta \\ 2 Jurusan Arsitektur, FTSP Universitas Trisakti \\ 1titikwidiyastuti21@gmail.com, 2mi.ririk@trisakti.ac.id
}

Diterima: 28-08-2020 Direview: 07-09-2020 Direvisi : 21-11-2020 Disetujui: 22-11-2020

\begin{abstract}
ABSTRAK. Bandar Udara Internasional Soekarno-Hatta merupakan pintu gerbang ke berbagai negara/daerah maka bentuk bangunan terminal penumpang dapat memberikan ciri khas atau identitas atau karakter visual bagi kawasan bandar udara dan memberikan keindahan saat dilihat dari sisi udara dan sisi darat. Terminal penumpang merupakan bangunan yang dapat menampilkan karakter visual bandar udara. Karakter visual dapat dirasakan oleh setiap pengguna bandar udara yang terlihat pada fasad bangunan. Fasad pada Terminal Penumpang bandar udara memiliki peranan penting dalam mempresentasikan dan memudahkan masyarakat untuk mengenal Bandar Udara sebagai ciri khas kawasan , sehingga fasad terminal penumpang perlu dikaji elemen-elemennya yang dapat menampilkan karakter bangunannya. Penulisan ini bertujuan mengidentifikasi elemen fasad pada bangunan terminal 1 , terminal 2 dan terminal 3 . Metode yang digunakan pada penulisan ini adalah metode kualitatif dengan mendeskripsikan karakter fasad bangunan terminal penumpang. Dari hasil analisis maka didapatkan karakter fasad bangunan terminal penumpang Bandar Udara Internasional Sooekarno-Hatta berupa atap, pintu, jendela dan ornament.
\end{abstract}

Kata kunci : fasad, terminal penumpang, bandar udara

ABSTRACT. Soekarno-Hatta International Airport is the gateway to various countries/regions, so the passenger terminal building's shape can provide characteristics or identities or visual character for the airport area and provide beauty when viewed from the airside and the side of the ground. The passenger terminal is a building that can display the visual character of the airport. The visual character can be felt by every airport user seen on the façade of the building. The facade of the airport Passenger Terminal has an essential role in presenting and making it easier for the public to know the airport as a characteristic of the area. The façade of the passenger terminal needs to be reviewed; its elements that can display the character of the building. This writing aims to identify the facade elements in terminal 1, terminal 2, and terminal 3. The method used in this paper is a qualitative method by describing the character of the façade of the passenger terminal building. From the results of the analysis, it is found that the character of the facade of the passenger terminal of Soekarno-Hatta International Airport in the form of roofs, doors, windows, and ornaments.

Keywords: façade, passenger terminal, the airport

\section{PENDAHULUAN}

\section{Latar Belakang}

Bandar Udara merupakan pintu gerbang ke berbagai negara/daerah, bentuk bangunan terminal dapat memberikan ciri khas atau identitas atau karakter visual bagi kawasan bandar udara dan memberikan keindahan. Desain bandar udara harus tetap abadi dalam karakter, bentuk, dan semangat saat dilihat dari sisi udara dan sisi darat. Terminal Penumpang adalah bangunan utama dari sistem bandar udara memiliki citra yang sangat berbeda dalam desain dan karakternya. Arsitekturnya mencerminkan kemewahan, skala, kekuatan struktural, daya tarik estetika. dan kecanggihan teknologi industri yang berkembang pesat ini.

Bandar Udara Internasional Soekarno-Hatta memiliki beberapa fasilitas bangunan dan infrastrukur yang mendukung kegiatan operasional bandar udara dan 3 (tiga) Terminal penumpang sebagai bangunan pelayanan penumpang merupakan bangunan yang mendukung kegiatan pelayanan penumpang yang akan terbang/mendarat dari pesawat udara. Ketiga terminal penumpang tersebut mempunyai karakter visual yang berbeda-beda apabila diamati pada tampilan fasad bangunan. Tampilan fasad bangunan mempunyai daya tarik tersendiri dilihat dari 
aspek arsitektur yang berfungsi untuk eksisternsi bangunan itu sendiri.

Fasad merupakan sisi luar (eksterior) dari sebuah bangunan, dengan bagian utama pada sisi depan, sisi samping atau belakang bangunan. Fasad bangunan pada dasarnya sebagai pelindung gedung dari gangguan luar, seperti cuaca buruk, hujan, angin, polusi dan panas. fasad pada arsitektur Terminal bandar udara memiliki peranan penting dalam mempresentasikan dan memudahkan masyarakat untuk mengenal Bandar Udara sebagai ciri khas kawasan.

Fasad sangat berkaitan dengan elemen dinding permukaan yang terdiri atas bidang void dan tekstur material seperti plester, batu dan kaca. Krier (1996:36) menjelaskan bahwa komposisi fasade harus mempertimbangkan semua persyaratan fungsional seperti jendela, bukaan pintu, pelindung matahari, dan bidang atap. Penampilan fasad bangunan berhuhungan erat dengan adanya kesatuan harmonis antara proporsi, pengaturan penggunaan struktur vertikal dan horisontal, ritme (irama), material, warna dan elemen dekoratif. Fasade terdiri dari komposisi elemen seperti pintu masuk arcade, lantai dasar, jendela, balkon, serta atap. Element fasad yang berbeda membentuk suatu ciri-ciri visual tertentu bagi masing-masing bangunan.

Pengembangan Bandar Udara Internasional Soekarno-Hatta yang ber berpengaruh pada perubahan fasad bangunan terminal yang diperbaharui seharusnya menandakan adanya identitas daerah setempat, namun terlihat pada fasad bangunan terminal 3 yang merupakan bangunan baru tidak menyesuaikan fasad bangunan terminal 1 dan 2 yang merupakan bangunan lama. Langgam arsitektur bangunan terminal 3 dengan konsep modern dan tidak terlihat menampilkan ciri khas budaya setempat, sedangkan pada bangunan terminal 1 dan 2 terlihat dari fasad bangunan masih menonjolkan sentuhan arsitektur Indonesia seperti pada penggunaan bentuk atap limas/joglo, material bata teracota yang menyerupai bata merah, ornament dan warna bangunan.

Berdasarkan Bill Raun, dalam Arsitektur Kontekstual menekankan bahwa sebuah bangunan harus mempunyai kaitan dengan lingkungan atau bangunan yang berada disekitarnya. Keterkaitan tersebut dapat dibentuk melalui proses menghidupkan kembali bangunan lama ke dalam bangunan baru sesudahnya, Sehingga menggunakan pendekatan arsitektur kontektual yaitu dengan netode perancangan yang mengkaitkan dan menyelaraskan bangunan baru dengan krakteristik lingkungan sekitar. Menurut Carmona et al. (2003) menjelaskan kriteria "integrasi yang harmoni" yaitu Karakter Volume, Karakter Visual, dan Sosial fungsional. Akan tetapi pada fasad bangunan baru yang akan di bangunan harus mempunyai nilai-nilai dari bangunan sekitar, sehingga Karakter Visual bangunan sekitar sangat mempengaruhi bentuk fasad pada bangunan baru.

Permasalah yang terdapat pada kawasan : Adanya perbedaan fasad bangunan terminal lama (1 dan 2) dengan bangunan baru (terminal 3) yang kurang mencerminkan karakter visual kawasan Diperlukan identifikasi elemen fasad bangunan terminal 1,2 dan 3 berdasar pada bangunan dan karakter fasad

Tujuan penulisan ini adalah :

Menganalisa karakter fasad bangunan terminal 1,2 dan 3 dengan mengidentifikasi fasad bangunan eksisting yang dapat mewujudkan karakter bandar udara dan dapat sebagai tolak ukur bagi perancangan fasad bangunan terminal baru

\section{METODE PENELITIAN}

Metode Penelitian yang digunakan adalah metode kualitatif, dengan variabel karakter visual dan variabel fasad

Tahapan yang dilakukan pada penelitian ini adalah : Pengumpulan data primer (survei) berupa data eksisting fasad bangunan terminal 1, terminal 2 dan terminal 3 dan data sekunder berupa : literatur, referens, Tahap analisa yaitu mengidentifikasi fasad bangunan terminal 1, terminal 2 dan terminal 3 berdasarkan variabel karakter visual Carmona \& Punter (2013); Ching, (2000), antara lain Garis bangunan (kolom), Ornamen, Material (bahan) dan warna, Pintu masuk, Bukaan (jendela), Atap bangunan, kemudian tahap berikutnya tahap hasil analisa dan kesimpulan.

\section{HASIL DAN PEMBAHASAN}

Dalam penelitian ini pembahasan karakter fasad bangunan terminal penumpang di Bandar Udara Internasional Soekarno-Hatta dibatasi oleh teori Carmona \& Punter (2013) dan (Ching, (2000) dengan elemen fasad bangunan; pintu, bukaan/jendela, atap, ornamen dan kolom yang dapat mewakili semua unsur fasad bangunan terminal. 


\section{ANALISA KARAKTER FASAD BANGUNAN TERMINAL 1, 2 DAN 3}

\section{a. Atap}

\section{Atap pada terminal 1 dan 2}

Ada 3 tipe bentuk atap yang digunakan pada bangunan terminal. Terminal 1 dan terminal 2 menggunakan bentuk atap joglo, pelana dan sebagian dengan atap datar. Atap joglo pada terminal mengadopsi bentuk atap joglo jawa yang sdh dimodifikasi dengan sentuhan modern

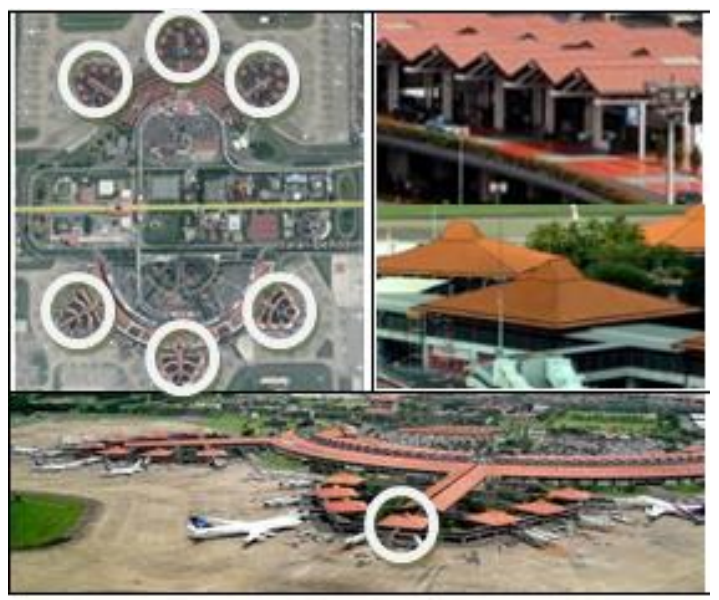

Gambar 1. bentuk bangunan dan atap joglo pada terminal 1 dan 2
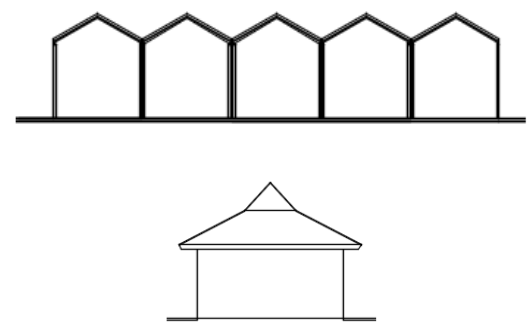

Gambar 2. Sketsa bentuk atap pelana dan joglo limasan pada terminal 1 dan 2

Bentuk massa yang menyebar dihubungkan koridor sesuai dengan bentuk atap limas joglo dengan luas massa yang sedang. Rangkaian massa yang menyebar dan mempunyai irama yang teratur dalam satu kesatuan membentuk satelit yang dihubungkan koridor bentuk pier yang terlihat dari atas.

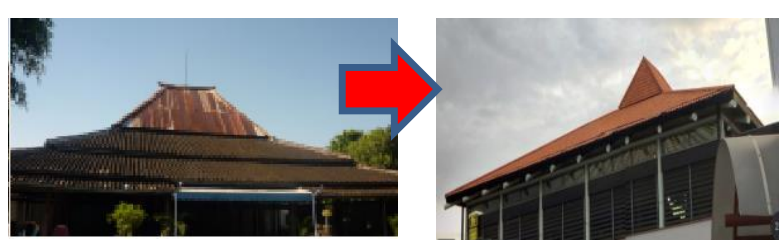

Gambar. 3. Bentuk atap joglo asli mempunyai 3 tingkatan yang diadopsi bentuk atap terminal $1 \& 2$.

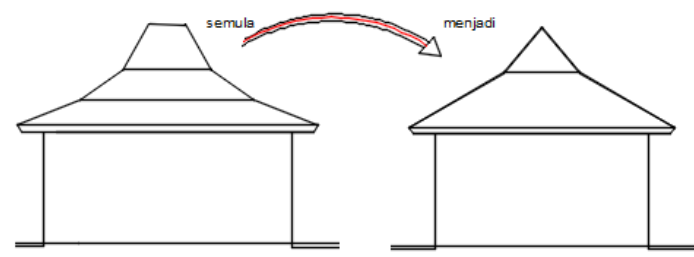

Gambar. 4. Sketsa bentuk atap joglo asli mempunyai 3 tingkatan diadopsi bentuk atap terminal 1 \& 2.

Sebagai bangunan publik tingkatan $\mathrm{dlm}$ atap joglo dikurangi 1 yang mempunyai hirarki tingkatan pemakai untuk kalangan bawah, menengah dan atas

Pada mulanya filosofi gunung ini diwujudkan ke dalam bentuk atap, yang kemudian dikenal sebagai atap Tajug. Seiring berjalannya waktu, bentuk atap tajug mengalami perubahan menjadi atap joglo, limasan, dan kampung (Hermawan \& Prihatmaji, 2019).

\section{Atap pada terminal 3}

Bentuk atap pada terminal 3 adalah melengkung panjang menyesuaikan bentuk bangunan linier dan pier finger serta menampilkan bangunan yang tinggi, megah dengan teknologi material. Bahan penutup atap adalah metal dengan warna silver yang tidak menyilaukan bagi pilot dan memberi kesan modern. Struktur atap bentang lebar dengan jarak antar kolom lebar memberi nuansa keleluasan sirkulasi dan view di dalam terminal yang lapang. 

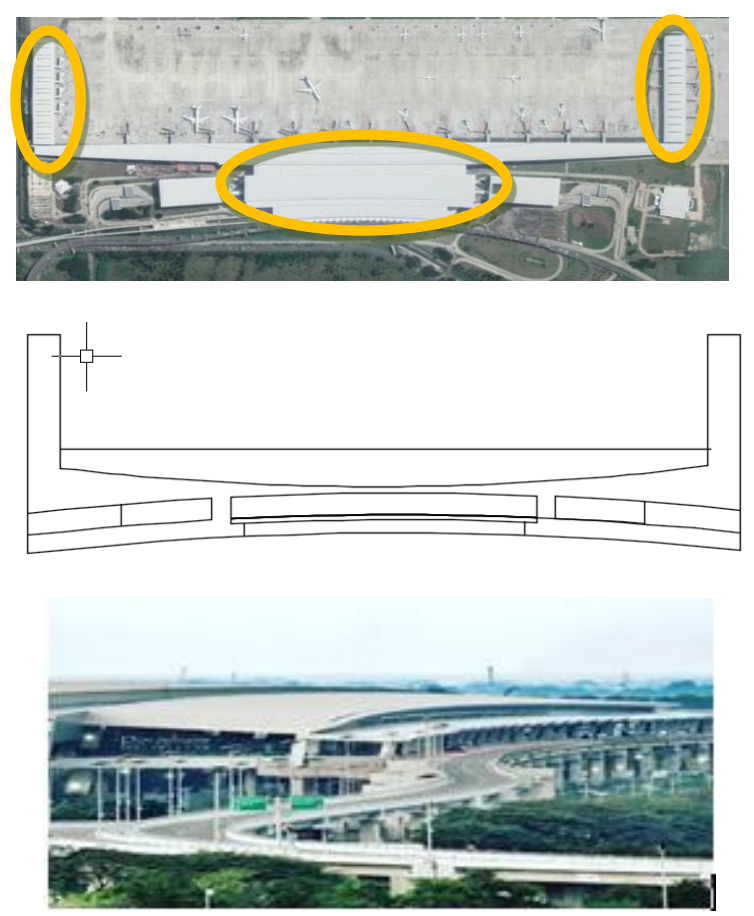

Gambar 5. Bentuk bangunan terminal 3 dengan konsep linier dan pier finger Sumber : yusufabdurahman.com, 2020
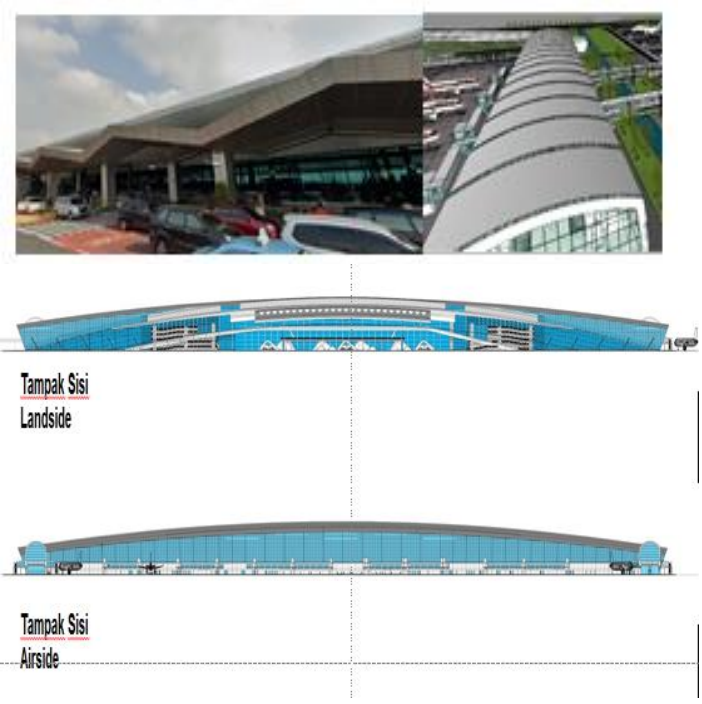

Gambar 6 . Bentuk atap pada terminal 3

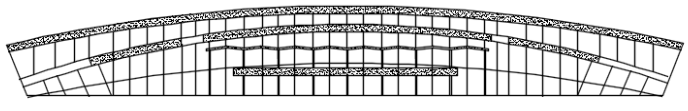

Bentuk atap kombinasi melengkung dan pelana

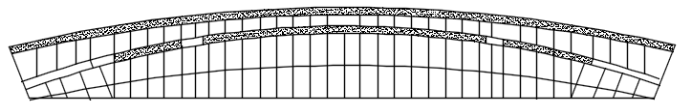

Bentuk atap melengkung

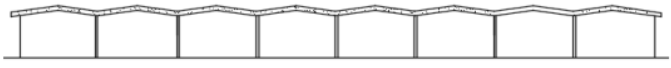

Bentuk atap pelana

Gambar 7. Sketsa bentuk atap melengkung dan pelana pada terminal 3

\section{b. Pintu masuk}

Pintu masuk pada terminal 1 berada Pintu masuk area entrance tidak ditengah bangunan, karena ada 2 pintu yaitu keberangkatan dan kedatangan dalam 1 lantai. Sedangkan pintu masuk terminal 2, ada 3 pintu masuk keberangkatan ( 2 gate keberangkatan domestic \& 1 gate keberangkatan Internasional) juga tidak ditengah-tengah bangunan yang berada pada lantai 2 gedung terminal. Di sekeliling pintu masuk ada list yang menandakan perbedaan dengan kaca bukaan pintu atau jendela lainnya supaya penumpang terarah memasuki pintu masuk keberangkatan. Pintu masuk terminal adalah pintu otomatis karena sering dilewati penumpang supaya tidak selalu bukatutup oleh setiap orang. Material pintu adalah kaca tempered untuk memudahkan petugas mengawasi penumpang dan pengunjung yang akan masuk ke terminal melalui pemeriksaan 

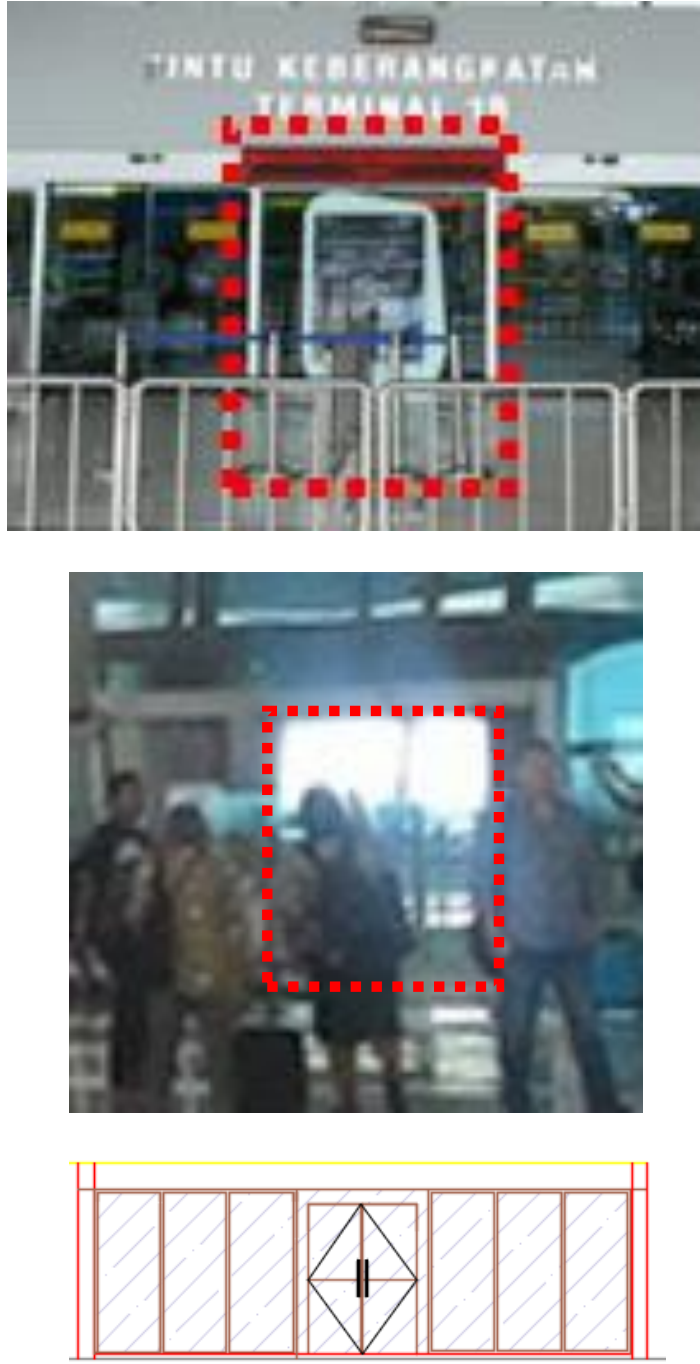

Gambar 8. Pintu masuk terminal 1 dan 2

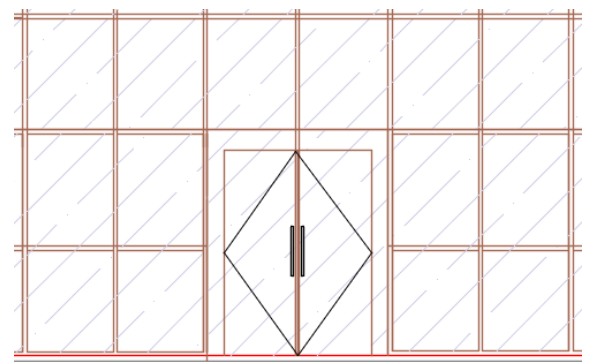

Gambar 9. Pintu masuk terminal 3

\section{c. Bukaan (Jendela)}

Pada terminal 1 dan 2 bukaan jendela berbentuk persegi selebar dinding fasade di area pintu keberangkatan/ kedatangan, sedangkan di area konsesi bukaan berupa pintu rolling door/folding door yang pada saat operasional di buka untuk pelayanan penumpang dan pengunjung. Bentuk jendela persegi dg kaca tempered yang lebar, tanpa bukaan (jendela mati) dengan bahan kaca tempered $12 \mathrm{~mm}$ dan kosen allumunium, tinggi jendela lantai 1 mulai dari atas permukaan lantai sampai plafon dengan tinggi sekitar 3-4 meter dan tinggi jendela lantai 2 sama.
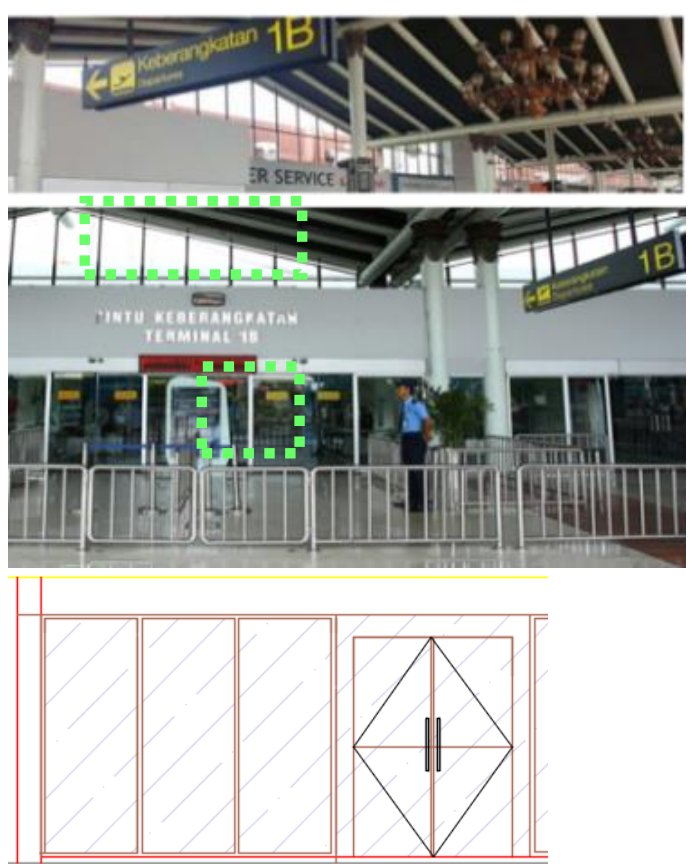

Gambar 10. Jendela kaca terminal 1 dan 2
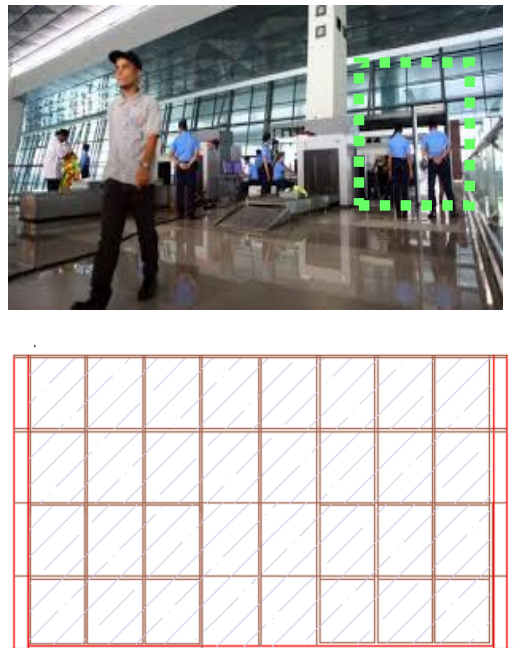

Gambar 11. Jendela kaca terminal 3

Bentuk jendela persegi lebar, tanpa bukaan (jendela mati) dan struktur kolom yang menjulang dan berulang membentuk irama garis yang teratur dan estetik yang memberikan kesan arsitektur yang megah. Fungsi jendela kaca untuk view dari dalam bangunan atau dari luar bangunan, untuk pencahayaan alami di siang hari dan sebagai pembatas antar fungsi ruang. Material kaca tempered dan laminated $12 \mathrm{~mm}$ supaya tidak 
mudah pecah apabila kena benturan benda keras, trolley atau lainnya.

\section{d. Ornamen}

Ornamen yang digunakan pada terminal 1 dan 2 adalah ornament dengan motif flora yang saling menembus pada sambungan balok dan kolom dengan warna natural/earth tone, Hijau, kuning.
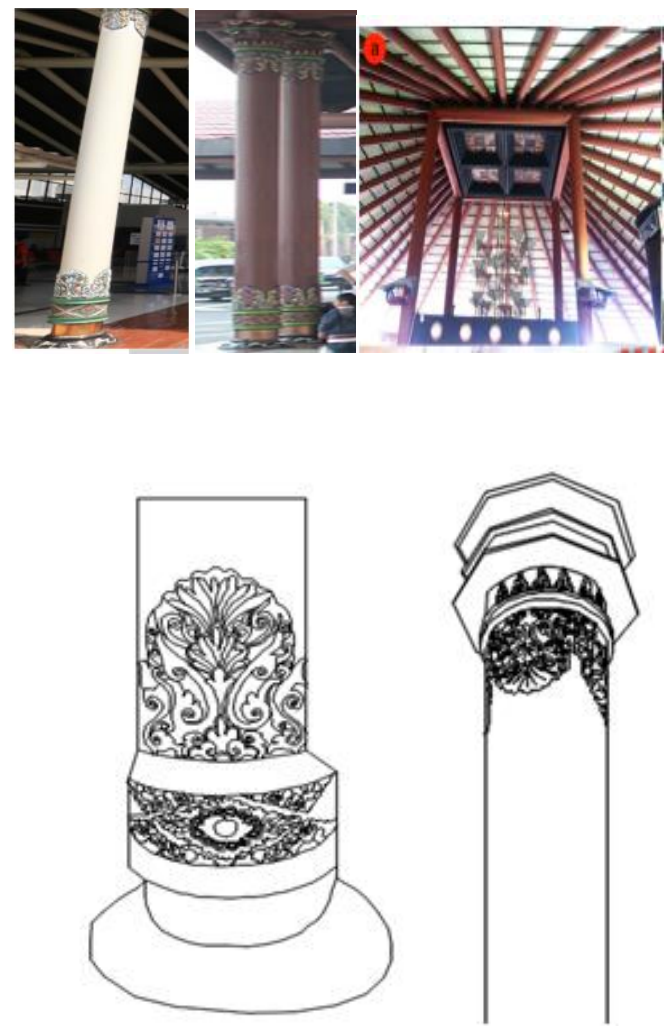

Gambar 7. Ornamen pada terminal 1 dan 2 untuk kolom, dinding atau elemen lain.

Ornamen yang sesuai untuk memberikan nuansa lokal bisa berupa motif ukiran khas Indonesia motif flora, motif batik, perpaduan motif flora dan fauna dengan warna disesuaikan dengan warna bangunan terminal keseluruhan atau warna-warna alam. Penempatan ornament bisa di kolom, dinding, plafon atau di elemen bangunan yang lain yang bisa terlhat oleh pengamat/pengguna bandar udara dan bisa menjadikan karakter visual terminal.

Pada terminal 3 ornamen pada fasad tidak ada yang ditampilkan, namun di ruang dalam terminal ada ornament lokal diatas counter check-in, karya seni daerah di antara island check-in, dan ragam hias di ruang tunggu. Secara tampilan fasad terminal 3 belum mengakomodir elemen lokal. Sehingga terkesan tidak mempunyai identitas lokal.
Tabel 1. Karakter fasad bangunan terminal 1 , 2 dan 3

\begin{tabular}{|c|c|c|c|c|}
\hline \multirow{2}{*}{ No } & \multicolumn{4}{|c|}{ Karakter fasad bangunan terminal $1 \& 2$} \\
\hline & Atap & $\begin{array}{l}\text { Pintu } \\
\text { masuk }\end{array}$ & $\begin{array}{c}\text { Jendel } \\
a\end{array}$ & Ornamen \\
\hline 1 & $\begin{array}{l}\text { Bentuk } \\
\text { atap } \\
\text { joglo } \\
\text { modern } \\
\text {,pelana }\end{array}$ & $\begin{array}{l}\text { Persegi } \\
\text { bukaan } \\
\text { dobel }\end{array}$ & $\begin{array}{l}\text { Persegi } \\
\text { bukaan } \\
\text { dobel }\end{array}$ & $\begin{array}{l}\text { Ukiran motif } \\
\text { flora/fauna/ma } \\
\text { nusia, } \\
\text { Karya seni } \\
\text { daerah, } \\
\text { patung, } \\
\text { schlupture }\end{array}$ \\
\hline 2 & $\begin{array}{l}\text { Material } \\
\text { gen } \\
\text { teng, } \\
\text { metal } \\
\text { sheet }\end{array}$ & $\begin{array}{l}\text { Material } \\
: \text { Kaca } \\
\text { tempere } \\
\text { red } \\
12 \mathrm{~mm} \\
\text { dan } \\
\text { alumuni } \\
\text { um }\end{array}$ & \begin{tabular}{|l} 
Kaca \\
temper \\
ed \\
$12 \mathrm{~mm}$ \\
dan \\
alumun \\
ium
\end{tabular} & $\begin{array}{l}\text { Kayu, logam, } \\
\text { kain, semen, } \\
\text { besi, raisin }\end{array}$ \\
\hline 3 & $\begin{array}{l}\text { Warna : } \\
\text { natural }\end{array}$ & $\begin{array}{l}\text { Warna } \\
\text { : silver }\end{array}$ & $\begin{array}{l}\text { Warna } \\
\text { : silver }\end{array}$ & \begin{tabular}{|l|} 
Warna: \\
Merah, \\
hijau,kuning, \\
hitam, putih, \\
natural \\
\end{tabular} \\
\hline & $\begin{array}{l}\text { Atap } \\
\text { kombinas } \\
\text { i joglo } \\
\text { modern } \\
\text { dan } \\
\text { pelana, } \\
\text { bahan } \\
\text { genteng, } \\
\text { metal } \\
\text { sheet }\end{array}$ & (1) & 1 & $\begin{array}{l}\text { Ukiran motif } \\
\text { flora/fauna }\end{array}$ \\
\hline No & Kara & akter fasa & bangunal & terminal 3 \\
\hline & Atap & $\begin{array}{l}\text { Pintu } \\
\text { masuk }\end{array}$ & Jendela & Ornamen \\
\hline 1 & $\begin{array}{l}\text { Bentuk } \\
\text { atap } \\
\text { melengk } \\
\text { ung dan } \\
\text { pelana }\end{array}$ & $\begin{array}{l}\text { Persegi, } \\
\text { bukaan } \\
\text { dobel }\end{array}$ & $\begin{array}{l}\text { Persegi, } \\
\text { bukaan } \\
\text { dobel }\end{array}$ & \begin{tabular}{|l|} 
Di sisi luar \\
terminal tidak \\
ada ornamen
\end{tabular} \\
\hline 2 & $\begin{array}{l}\text { Material } \\
\text { : metal } \\
\text { sheet }\end{array}$ & $\begin{array}{l}\text { Material } \\
\text { : Kaca } \\
\text { temprer } \\
\text { ed } 14 \\
\text { mm dan } \\
\text { alumuni } \\
\text { um } \\
\end{array}$ & \begin{tabular}{|l|} 
Material \\
: Kaca \\
temprer \\
ed 14 \\
mm dan \\
alumuni \\
um \\
\end{tabular} & $\begin{array}{l}\text { Di dalam } \\
\text { terminal ada } \\
\text { ornament } \\
\text { berupa karya } \\
\text { seni daerah, } \\
\text { ukiran logam }\end{array}$ \\
\hline 3 & $\begin{array}{l}\text { Warna } \\
\text { silver/ } \\
\text { netral }\end{array}$ & $\begin{array}{l}\text { Warna: } \\
\text { silver }\end{array}$ & $\begin{array}{l}\text { Warna: } \\
\text { silver }\end{array}$ & $\begin{array}{l}\text { Warna : coklat, } \\
\text { silver, putih }\end{array}$ \\
\hline & & $\mathbb{I V}$ & 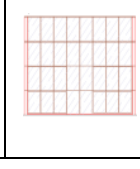 & $\begin{array}{l}\text { Tidak ada } \\
\text { ornamen }\end{array}$ \\
\hline
\end{tabular}




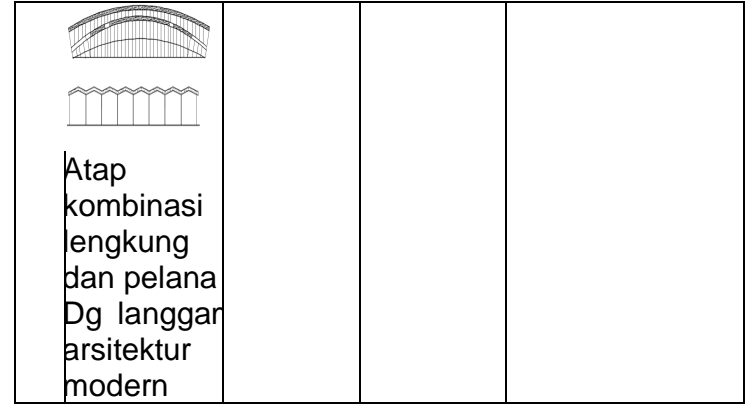

Analisis fasad bangunan terhadap langgam arsitektur tradisional dan modern (Sumalyo, 2005):

- Langgam arsitektur Tradisional Pintu masuk berada di tengah-tengah bangunan, jendela tidak besar dengan bahan kayu ada kantilever di atas jendela. Bentuk atap jawa limas, joglo, dan bentuk lainnya menyesuaikan budaya setempat, umumnya denga tambahan tritisan di sekeliling bangunan untuk menanggulangi tampias hujan dan terik panas matahari, karena Indonesia beriklim tropis.

elemen estetika berupa "Ornamen" yang menggambarkan tentang kehidupan pada umumnya bermotif flora dengan sulursulurnya dan bentuk laian seperti fauna/ binatang.

- Langgam arsitektur Modern

Pintu material mulai dari kaca, aluminium, beton, hingga besi baja. Dengan bentuk modular

Jendela lebar dengan material kaca clear diwujudkan untuk menyatunya ruang dalam dan ruang luar, jarak antar kolom relative lebar, saling berhubungan secara berkesinambungan, Bentuk atap bervariasi sesuai bentuk massa dan fungsi bangunan, seperti datar, melengkung, trapecium, dll. Tidak ada ornament, bangunan lebih sederhana

\section{KESIMPULAN}

Berdasarkan hasil analisa karakter visual bangunan di Bandar Udara Internasional Soekarno-Hatta dengan menggunakan analisa Carmona \& Punter (2013); Ching (2000) dan langgam arsitektur Indonesia maka dapat disimpulkan bahwa karakter fasad bangunan terminal 1 dan terminal 2 ditinjau dari bentuk atapnya mencirikan gaya arsitektur tradisional dengan sentuhan modern (neo-vernakuler) yaitu bentuk atap joglo yang sudah dimodifikasi dengan sentuhan modern, sedangkan pada terminal 3 mempunyai gaya arsitektur modern bentuk atap melengkung dengan material atap metal sheet dan warna netral/silver yang tidak mengkilat. Sentuhan lokal yang terdapat pada terminal 1 dan 2 adalah ornament pada kolom,dinding dan plafon berupa ukiran dengan motif flora yang berwarna natural, merah, hijau atau kuning sesuai dengan kolom / dinding yang dijadikan media untuk menempelnya.

Melihat secara keseluruhan dan pengembangan bangunan terminal yang mengikuti kemajuan teknologi, maka fasad bangunan terminal penumpang Bandar Udara Soekarno-Hatta menampilkan karakter modern dengan sentuhan tradisional yang diterapkan pada unsur garis atap limas dan ornament pada bangunan terminal

\section{UCAPAN TERIMA KASIH}

Terima kasih kepada Universitas Trisakti Program Studi Arsitektur yang telah memberi arahan dan bimbingan dalam menyelesaikan penulisan ini.

\section{DAFTAR PUSTAKA}

Carmona, M, \& Punter, J. (2013). The Design Dimension of Planning: Theory, Content and Best Practice for Design Policies. United Kingdom: Routledge.

Carmona, Mathew ... Taner Oc. (2003). Urban Places Urban Space. London: Architectural Press.

Ching, F. D. (2000). Arsitektur, Bentuk, Ruang dan Susunannya (ke-2). Jakarta: Erlangga.

Hermawan, B., \& Prihatmaji, Y. P. (2019). Perkembangan Bentukan Atap Rumah Tradisional Jawa. Prosiding Seminar Nasional Desain Dan Arsitektur (SENADA), 2, 387-393.

Sumalyo, Y. (2005). Arsitektur Modern Akhir Abad XIX dan Abad XX. Yogyakarta: Gadjah Mada University Press. 
